\title{
Research on existing building space based on the view of sponge City_-Taking the bauhinia garden in Tongzhou district of Beijing as an example
}

\author{
JIANG Qi-qi ${ }^{1}$ \\ ${ }^{1}$ Academy of fine arts, Shanxi University, Taiyuan, Shanxi, China
}

\begin{abstract}
As the residential area with the largest proportion in the urban functional division, the matrix distribution range is the largest in the rainwater flow path, and it is also an important part of urban sponge implementation. The article explores the sponge transformation of the existing space of Bauhinia Garden, analyzes the existing problems within the community, gives adaptive advice on relevant issues and summarizes relevant experiences. In order to provide experience for the subsequent renovation of the sponge community, it is necessary to restore the water circulation function of the community.
\end{abstract}

\section{Introduction}

The construction of sponge city is the embodiment of the quality of life of urban residents, which plays an important role in regulating the air inside the city and alleviating the heat island effect. In the Rain Water season, where heavy rain occurs frequently, the construction of sponge city can quickly absorb, divert and purify the water, avoid local water accumulation on the ground, facilitate people's daily life and ensure the safety of property life; in the dry season with scarce rainfall, it can release the saved water into the air and improve the air quality.

The construction time of sponge city in China is relatively late, and most of the functional roads in the city are made of impermeable asphalt and concrete. As a result, it is difficult to recycle Rain Water resources in the city. A large number of Rain Water flows into the groundwater area through the surface to increase the pressure of groundwater system, and it is difficult to make secondary utilization of Rain Water resources, which makes a large amount of waste of water resources.

\section{General situation and design principles of Bauhinia garden}

\subsection{Overview}

The Bauhinia Garden is an existing cell with a long time in Tongzhou District, Beijing. It has been completed from the beginning to now for seventeen years. Tongzhou District, as the sub-center of Beijing City, has received extensive attention. As a model of Tongzhou's residential district, Tongzhou District has become the first one of Beijing's first cell sponge transformation objects in 2017.
The cell is located between the peony road and the east six rings, the total occupied area of the building is 23439 square meters, the green area accounts for one third of the total area of the cell, and the average annual rainfall is $652.1 \mathrm{~mm}$ [1]. The topography of the cell is distributed in the north-east high-west and low-southwest, but the whole area of the Zijing Yayuan community is lower than that of the surrounding area.

Although there are many problems in the district, the terrain is undulating and the underlying surface matrix is complex, but it is representative in the construction of sponge city. Through the analysis and investigation of the rainfall in the district, the formula of rainstorm intensity is $\mathrm{Q}=2728$ (10.767 2lg P) / ( 13457 7) 0.738 6. Taking the design standard as an example, according to the above rainstorm intensity formula, the rainfall duration of 5,15 , $30,45,60,90 / 120$ min can be calculated, as shown in Table 1.

Table.1. Surface Rain Water runoff and rainfall in different time periods

\begin{tabular}{|c|c|c|c|c|c|c|c|}
\hline Rainfall time & 5 & 15 & 30 & 45 & 60 & 90 & 120 \\
\hline Rainfall & 12.8 & 26.4 & 40.9 & 51.2 & 57.9 & 67.3 & 71.8 \\
\hline
\end{tabular}

\subsection{Sponge design}

\subsubsection{Low impact principle}

In the construction of sponge city, the soil type, terrain trend, climate condition, human flow line and other related factors in the community are fully understood, and the natural attributes of the district are paid attention to. Reduce the interference to the original environment around the existing building as much as possible during the construction period. 


\subsubsection{Principle of facility reliability}

In the process of sponge city construction, safe and reliable facilities should be used for paving and placement. High quality building materials can make the facilities play the greatest benefit, ensure that Rain Water will be quickly drained, absorbed and filtered during the peak period of Rain Water drainage, to achieve no water accumulation on the road surface and to put an end to the occurrence of waterlogging, so as to provide protection for the lives and property of residents.

\subsubsection{Economic principle}

In the selection of spongy building materials, attention should be paid to the service life of the building materials themselves and the cost of their later maintenance. The use of high quality, wear resistance and high strength materials can enhance its service cycle; high technology, the use of new materials is convenient for later repair, nursing; multiple angles to increase the performance-price ratio of sponge facilities, and strive to maximize economic benefits.

\section{Analysis of the current situation of the cell}

\subsection{The underlying substrate and the present status of the terrain}

The lower cushion surface filling is mainly made of artificial fill, with less primary soil, with a depth of about 3 meters, a permeability coefficient of $1.05-10-7 \mathrm{~cm} / \mathrm{s}$, and low permeability the substrate rainwater permeability from being low when the rainfall is prevented, so that the rainwater can not be absorbed in time, and the rainwater can be drained, so that the water logging in the south is serious.

\subsection{Conditions of traffic line}

The traffic streamline of the district is mainly divided into colloidal pavement and concrete impermeable pavement, accounting for $66.51 \%$. The construction years of the district are long, the internal traffic system is chaotic and no people and cars are separated; the main streamline road is concrete paving, the pavement skin is seriously damaged, and the phenomenon of pit depression is serious; the sidewalk is paved with impermeable pavement brick, and the road is damaged for a long time. The parking space accounts for $38.2 \%$ of the total road area, and the paving mode is hollowed-out grass brick, and the pavement matrix of traffic moving line is not conducive to LID transformation.

\subsection{Existing building facilities}

The top floor of the building is not paved with green roof vegetation, most of which is the bare original building plane and the self-building shed space of the residents. The drainage system is not perfect, only meets the basic rainwater collection and drainage function of the roof, and is directly discharged into the grass cluster through the rain water pipe, and the drainage pressure is caused to the surface rainwater runoff.

\subsection{Underground drainage network management system}

Rain Water sewage system in the community is perfect, rain pollution network management system does not exist mixed phenomenon. Rain Water, collected by underground pipeline during rainfall, is centrally filtered by residential property and discharged into the surrounding canal system after simple internal treatment. Because the technologically backward water quality is difficult to meet the national discharge standard, it pollutes the water quality of the surrounding rivers to a certain extent.

\subsection{Green plant and public space distribution}

The green area of the garden is one-third of the total area of the community, and the basic standard of the green efficiency of the residential community in China is achieved. The vegetation planting form of some lawns is on the rise in the space, which is higher than that of the road surface and is in the form of a gentle slope, which is beneficial to the distribution and drainage of the rainwater in the precipitation. The lack of public space and entertainment facilities has not applied the landscape design theory of the matrix, the plaque and the corridor to the functional planning of the community [2], and uses the corridor facilities to organically combine the patches in the small areas to enrich the living and living of the residents.

\section{An example of the reconstruction of Bauhinia Ya garden}

\subsection{Road system renovation}

The pavement of the sidewalk is paved with waterpermeable brick, and the motor-driven vehicle is paved with water-permeable concrete. (Figure 1) The preferred material of the particles with a bulk density of $800 \mathrm{~kg} / \mathrm{m} 3$ and a water absorption of $17.8 \%$ is selected. And the rainwater can rapidly penetrate into the underground rainwater pipe network so as to reduce the water condition of the smooth road area.

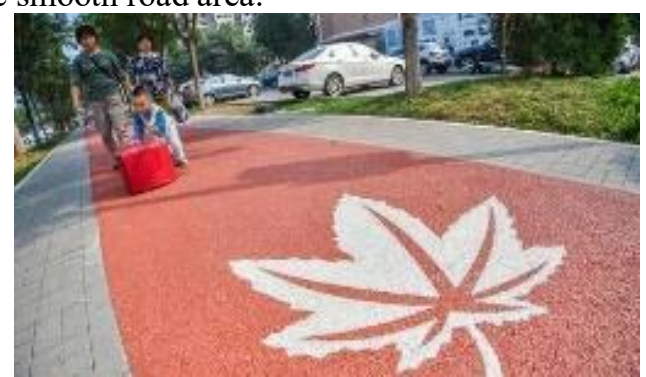

Fig. 1. Pedestrian road. Pictures come from the Internet 


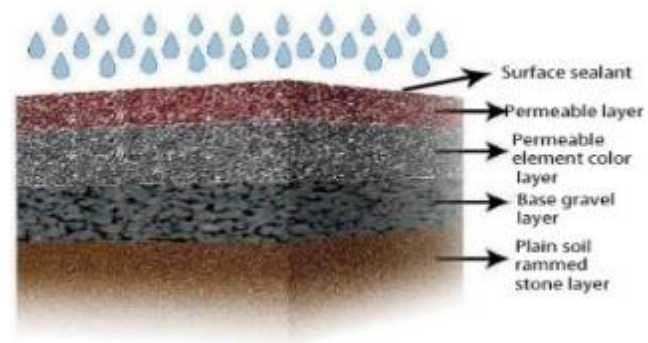

Fig. 2. Underlying surface structure. Pictures come from the Internet

\subsection{Soil structure design}

The lower surface of the vegetation is composed of a vegetation cover layer, a nutrient soil layer, a multinutrient concrete and a reinforcing structure layer, the porosity is more than 20 percent, the water permeability coefficient is ensured to be 1.8 , and the whole structure is distributed in a square cross reinforcing layer. The soil can be secondarily filtered and introduced into the underground water network system according to the structure of its own structure. It is absorbed by the sponge like a sponge, and is connected with the air when needed.

\subsection{Rain water garden}

The lower concave green space plays the role of Rain Water savings regulation in the construction of sponge city. The depth of soil layer fall, vegetation selection and pavement drainage runoff are all the key points of the design. In the range of $150 \sim 200 \mathrm{~mm}$, slope, the vegetation planted on the gentle slope is mostly Arbor, shrubs and other plants with developed root system and strong vitality resistant to Rain Water scour can clean and block the sundries in Rain Water while draining Rain Water. the overflow well is set up in the lower concave green space, so that the excess 3500 is absorbed. Prevent heavy rainfall caused by Rain Water siltation and return overflow to the road.

\subsection{Rain water efflux control}

Through the application of LID implementation scheme, the surface height is adjusted and the geological matrix is improved, After the spongy facility of Garden is completed, $70 \%$ of Rain Water resources can continue to be recycled, and Rain Water control quantity in the district is $22 \mathrm{~mm}$ [3]. During heavy rainfall, the peak value of discharge of strong Rain Water in 1 hour decreased by $63.2 \%$, and the peak drainage time slowed down by 8 minutes compared with before, which alleviated the treatment pressure of Rain Water in the city and realized the effect of water recycling. (Fig. 3)

\section{Surface Rain Water runoff}

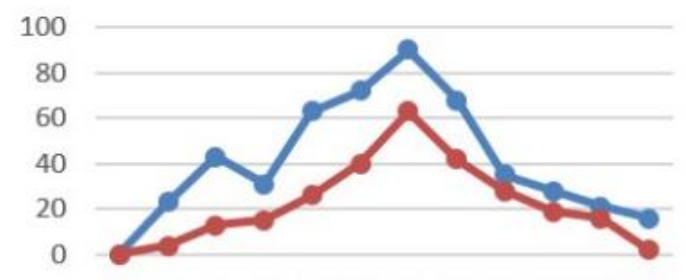

$10 \quad 20 \quad 30 \quad 4050 \quad 60 \quad 70 \quad 8090 \quad 100110120$

$$
\text { - Initial data }
$$

Fig. 3. Surface Rain Water runoff.

\subsection{Measures of landscape water transfer in residential areas}

In the reconstruction of the sponge city of the Vitex Arboretum, the visual and functional requirements of the landscape should be taken into play, and the effect of the regulation of water saving can be realized. The scale of the water body landscape was adjusted according to the rainfall, transpiration and water return of the urban climate. The water resources inside the landscape are primarily filtered, the ecological treatment and the organic circulation are carried out, and the internal water body is prevented from being stored for a long time, and secondary pollution is caused to the rainwater resources.

\section{Conclusion}

The internal sponge construction of the community can be continuously developed and the climate is adjusted by the environmental resources of the city, The secondary utilization of rainwater resources plays an important role. The construction of the sponge city can promote the rapid development of the urban environment, alleviate the heat island effect and improve the quality of life of the people.

\section{References}

1. J. Yu Zhonghai, Liu Xuwei. Discussion on the design method of spongy reconstruction system in built building district. Water supply and drainage in China, (2017) (7): 119 -123.

2. J. Zhang Ou. The design of the garden landscape rain system with low impact on the construction of the sponge city. Building materials and decoration, (2015), (20):113-115.

3. J. Wang Jianting. Study on the strategy of green transformation of existing residential areas based on the concept of sponge city. Eco-economy, (2016),32 (7):220-223. 